\title{
A UNIFIED FACTOR ANALYSIS AND DISTANCE BASED EVALUATION APPROACH TO EVALUATE THE PREFERENCES TOWARDS ONLINE FOOD ORDERING APPLICATIONS IN SAUDI ARABIA
}

\author{
Mohammad Faisal Khan* \\ Department of Basic Science, College of Science \& Theoretical Studies, Saudi Electronic \\ University, Riyadh-11673, Saudi Arabia \\ *Corresponding Author
}

\begin{abstract}
Owing to the hard-pressed way of life these days, online food applications have emerged as a trend. Everyone prefers to order food online, rather than cooking at home or eating home-cooked meals, in the search of flavor and variety. Advancing technology has been playing a significant role in the establishment and progression of online cellular food ordering applications of which HungerStation, Walem, Talabat, Daeemdelivery, Shadda, Careem Now, and Jahez are the most recurrent and frequently used applications by the customers in Saudi Arabia. In this paper, various factors are explored which influence the customers in the use of online food ordering applications by using Exploratory Factor Analysis (EFA). Four factors, namely Right Contents \& Packaging, Offers \& Discounts, Timely Delivery, and User-Friendly, are identified and then, based on these factors' preferences of customers towards the top four online food ordering apps of Saudi Arabia are evaluated by Evaluation Based on Distance from Average Solution (EDAS) technique.
\end{abstract}

Key words: Covid-19; Online Food Ordering Apps; Decision-Making; EFA; EDAS

Cite this Article: Mohammad Faisal Khan, A Unified Factor Analysis and Distance Based Evaluation Approach to Evaluate the Preferences towards Online Food Ordering Applications in Saudi Arabia, International Journal of Management, 11(12), 2020, pp 1752-1762.

http://iaeme.com/Home/issue/IJM?Volume=11\&Issue=12

\section{INTRODUCTION}

In this generation driven by technology, the World Wide Web has to turn out to be one of the genuinely influential kinds of media. As the usage of conventional offline media is diminishing, and the usage of virtual/online media is escalating, enterprises had to shift the 
direction of their work. One of the biggest causes of the development in the use of virtual/online media is due to the younger generations being too tech-savvy. To try to recover from falling sales, numerous prominent companies dealing in tourism, production, food, fashion, medicine, and many more have started to adopt the online business strategies that they can.

Businesses that are a part of the food industry have also started to adopt online strategies. The tradition of online restaurants has rapidly emerged, and currently, many new food businesses offer the option of customizing food orders with no physical store. These businesses use the online platform as a carrier to connect with their customers. The World Wide Web has also provided the same assistance to conventional restaurants to experience a surge in sales. It has also led to the conception of "middlemen" for restaurant businesses, such as the food ordering and delivery companies. These middlemen work towards establishing relationships with restaurants, and then they go on to listing the partnered restaurants on their online platform (i.e., websites or mobile applications). Customers can then go on these websites or applications and place their orders there. These middlemen generate their compensation through the commission fees received from the restaurants, delivery fees from customers, or both.

With the rise of the $21^{\text {st }}$ century, we could see Saudi Arabia at a rising pace. Youthful minds of the nation are significantly exceeding expectations in the time of most recent innovation and developments. People in the working class need to perform well in their associations, and creation is assuming an indispensable job in accomplishing the equivalent. Due to the busy lifestyle these days, online food ordering applications have emerged as a general trend. Each person prefers to order food online instead of cooking at home or eating the home-cooked food searching for taste and variety. Technology has played a significant role in the introduction and advancement of online food ordering applications.

The epidemic of novel coronavirus (Covid-19) has wreaked havoc across the world, including Saudi Arabia. Simultaneously, Covid-19 and simultaneously the sudden lockdowns have surged the demand for home food delivery services. Since dine-in is no longer an option, consumers are turning to home delivery service system during these days. Many restaurants have responded to the crisis by introducing contactless delivery options to eliminate the risk of spreading the virus between the staff and customers. There is one more reason; many restaurants do not have space to maintain social distancing. That is why they have chosen the home delivery option with the contact of these apps.

The things which appeared to be unimaginable are presently turning out to be conceivable considering the innovative progressions. Today, different sorts of organizations are setting up online stores because of innovation. Various factors, for example, less expensive cell phones and less costly web information packs, individuals have begun utilizing a greater amount of cell phone applications.

The online food ordering applications have made a lot of things much more advantageous for the users. Online food ordering can be characterized as a conveyance of food or take out from an eatery or a neighborhood food joint through a website page or portable App. The clients can order food from their preferred eateries based on the selection of cooking styles and conclude whether to get it conveyed to get from the eatery. They can also decide to pay from different modes, for example, cash on delivery (COD), plastic money, or some other electronic wallet.

In this paper, the factors responsible for decision making of online food ordering applications, (i.e., how the consumer decides which App to use if he prefers to order food online through these apps) are studied. Section 2 presents a detailed review of the literature. The questions of research are raised in section 3, whereas to get the answers to these research 
questions, the method has been discussed in section 4. Section 5 covers the data analysis and interpretation part. Finally, section 6 concludes the study followed by references.

\section{REVIEW OF THE LITERATURE}

Several researchers and academicians explore the area of food or cuisines from different perspectives. Some of the work done in this area are summarized below:

Ghadiyali (2017) [1] mentioned that a considerable rise in digital technologies has led to the surge in the food industry because of which Zomato has become one of the most popular online food ordering platforms. With the boom in the digital industry, the market size of food is anticipated to reach 42 lac crores by 2020. Firstly, these applications are designed to be trustworthy. Another major reason for the customers getting attracted to these apps is the special offers being provided by these applications. Further, the marketers advocate these apps through social media. Goyal and Singh (2007) [2] estimate the reputation of various reasons influencing the selection of fast-food stores by Indian young consumers. They also analyzed the factors such as consumption patterns, the impact of hygiene and nutritional values, and the rating of various attributes about McDonald's and Nirula's.

Kimes (2011) [3] observed that the surge in online food ordering is because of convenience and control, so much so that almost half of the population of U.S. has ordered food online. Some of the reasons for that would be: Getting to interact personally with restaurant employees, the level of satisfaction of consumers post ordering food online, and the change in behavior of the consumers regarding mobile food ordering applications. Dinners at home culture are confronting a move; it has become a pattern to feast out or to arrange perfect food at home in India as uncovered by Anand (2011) [4]. Kashyap et al. (2013) [5] say that the society nowadays is of the opinion that consuming inexpensive food is an elevated requirement of living whereas Banerjee et al.(2013) [6] studies about the awareness towards convenience food between the working and non-working women's.

Lee and Raiz (2015) [7]; Wright et al. (2015) [8] uncover that U.S.-based elderly individuals find support in diminishing the sentiment of forlornness by conveyed dinners. The forward leap of the twentieth century pushed the populace towards a new computerized way of life, bringing about changed dietary patterns is the opinion of Quevedo-Silva et al. (2016) [9]. Pigatto et al. (2017) [10] have found that the human has made considerable progress by making a substantial effort to get everything and to have everything now, on simply snap off a fingertip and therefore these applications are presently more sought after than any other time in recent memory. Sharma and Waheed (2018) [11] explored the extent of usage of online food apps among emigrant college students in Dubai.

Kapoor \& Madhu (2018) [12] have noticed that the conglomeration of online fooddelivery aggregators initiative of providing multiple options to consumers just by tapping on their phones, has made ease during pleasures. This market form has taken the competition to the next level, where many online portals for dine-in, dine-out, take away and home delivery have flooded the food market with many alternatives.

Reddy and Pentyala (2019) [13] have explored the influencing factors, their perceptions, needs, positioning of various attributes of different online portals in their mind, and overall satisfaction towards online food services. Prasad and Sharma (2016) [14] understand the influence of demographic and socioeconomic factors among the Indian populace on online channel usage and non-usage purchasing of food \& grocery.

Alalwan (2020) [15] identifies and empirically examines the main factors forecasting the e-satisfaction with mobile food ordering apps and customers' purpose to reuse such apps in Jordan. 
It is evident from the above literature review that in Saudi Arabia, the concept of online food ordering apps is not much explored, and especially the decision-making is not prevalent best of the authors knowledge.

\section{STATEMENT OF THE PROBLEM}

This study is conducted to find out the answers to the following questions.

1: Which factors are responsible for motivating customers to order food through online food ordering applications.

2: How the customers decide the preference for online food ordering applications.

\section{METHODS OF SOLUTION}

This section presents the methods used to explore the main factors of influence and to evaluate the preference of customers towards online food ordering applications.

\subsection{Exploratory Factor Analysis}

In a multivariate data reduction technique, Exploratory factor analysis (EFA), generally referred to as Factor analysis, is used to find the construct of a group of variables out of a large number of observed variables that might have interdependence among themselves. Two strategies for factor examination are commonly used, principal component analysis (PCA) and the maximum likelihood technique. The principle steps of PCA are portrayed in the following: (Tzeng et al., 2007 [16]; Saini \& Gupta, 2020 [17])

Step 1: Recognize the variance-covariance matrix for the construct (say $x_{j} ; j=1,2, \ldots, n$ ) to be evaluated.

$$
V=\left[\begin{array}{cccc}
V\left(x_{1}\right) & \operatorname{Cov}\left(x_{1}, x_{2}\right) & \cdots & \operatorname{Cov}\left(x_{1}, x_{n}\right) \\
\operatorname{Cov}\left(x_{2}, x_{1}\right) & V\left(x_{2}\right) & \cdots & \operatorname{Cov}\left(x_{2}, x_{n}\right) \\
\vdots & \vdots & \ddots & \vdots \\
\operatorname{Cov}\left(x_{n}, x_{1}\right) & \operatorname{Cov}\left(x_{n}, x_{2}\right) & \cdots & V\left(x_{n}\right)
\end{array}\right]
$$

Step 2: Discover the eigenvalues $\alpha_{k}, k=1,2, \cdots, m$ (where $\mathrm{m}$ is the number of factors, also to be determined) and eigenvectors $\left(\vartheta_{k}=\vartheta_{1 k}, \cdots, \vartheta_{i k}, \cdots, \vartheta_{p k}\right.$; where $\mathrm{p}$ is the number of variables) for measuring the factor loadings $\left(d_{i k}=\beta_{k} \vartheta_{i k}\right)$.

Step 3: Set the eigenvalue ordering $\left(\alpha_{1}>\cdots \alpha_{k}>\cdots \alpha_{m} ; \alpha_{m}>1\right)$ to choose the number of common factors, and select the number of common factors to be fixed obtained by a predetermined criterion.

Step 4: Use the of varimax principles to find the rotated factor loading matrix, which offers added understandings for the rotation of the factor-axis, according to Kaiser (1958) [18].

Step 5: Lastly, name the factors mentioning the grouping of apparent variables.

\subsection{Evaluation Based on Distance from Average Solution}

Steps involved in Evaluation Based on Distance from Average Solution (EDAS) are as follows (Sudha, 2019) [19]:

Step 1: Prepare a matrix of decisions, say A

$$
A=\left[\begin{array}{cccc}
a_{11} & a_{12} & \cdots & a_{1 n} \\
a_{21} & a_{22} & \cdots & a_{2 n} \\
\vdots & \vdots & \ddots & \vdots \\
a_{n 1} & a_{n 2} & \cdots & a_{n m}
\end{array}\right]
$$


where $a^{i j}$ denotes the preference rating of the $i^{t h}$ alternative on the $j^{t h}$ factor. All $a^{i j}$ are assumed to be positive numbers.

Step 2: Establish the average solution $\left(A_{j}\right)$ using the formula

$$
A_{j}=\frac{\sum_{i=1}^{n} a_{i j}}{n}
$$

Step 3: Compute the positive distances from the average (PDA)

$$
P D A_{i j}= \begin{cases}\frac{\max _{i}\left\{0,\left(a_{i j}-A_{j}\right)\right\}}{A_{j}}, & \text { if } j^{\text {th }} \text { criterion is beneficial, } \\ \frac{\max _{i}\left\{0,\left(A_{j}-a_{i j}\right)\right\}}{A_{j}}, & \text { if } j^{\text {th }} \text { criterion is non-beneficial, }\end{cases}
$$

Step 4: Compute the negative distances from the average (NDA)

$$
N D A_{i j}= \begin{cases}\frac{\max _{i}\left\{0,\left(A_{j}-a_{i j}\right)\right\}}{A_{j}}, & \text { if } j^{\text {th }} \text { criterion is beneficial, } \\ \frac{\max _{i}\left\{0,\left(a_{i j}-A_{j}\right)\right\}}{A_{j}}, & \text { if } j^{\text {th }} \text { criterion is non-beneficial, }\end{cases}
$$

Step 5: Calculate the weighted sums of $P D A_{i j}$

$$
S P_{i}=\sum_{j=1}^{m} w_{j} P D A_{i j}
$$

where $w_{j} ; j=1,2, \ldots, m$ are the weights associated with each factor.

Step 6: Calculate the weighted sums of $N D A_{i j}$

$$
S N_{i}=\sum_{j=1}^{m} w_{j} N D A_{i j}
$$

Step 7: Estimate the Normalized values of $S P_{i}$ and $S N_{i}$ as

$$
\begin{gathered}
N S P_{i}=\frac{S P_{i}}{\max _{i}\left(S P_{i}\right)} \\
N S N_{i}=1-\frac{S N_{i}}{\max _{i}\left(S N_{i}\right)}
\end{gathered}
$$

Step 8: Estimate the appraisal scores $\left(A S_{i}\right)$ by taking the average of $N S P_{i}$ and $N S N_{i}$ as

$$
A S_{i}=\frac{1}{2}\left(N S P_{i}+N S N_{i}\right)
$$

Step 9: Corresponding to the decreasing values of appraisal scores $\left(A S_{i}\right)$ the alternatives are ranked. Let $\max A S_{i}=A S_{k}$. Then $\mathrm{k}$ is the most excellent option among the other alternatives.

\subsection{Methodology used}

The study conducted a survey that aimed at identifying if people are aware of the whole concept of online food ordering and if they are, then how extensive their knowledge is and how frequently they use it. The primary study was on how they decide as to which App to use and what are the factors that affect their decision making. Therefore, the study is based on experimental and analytical research design. Exploratory research design has been used to identify the factors that motivate the people of Saudi Arabia towards the usage of online food 
ordering apps, and analytical design has been used to make the decision clearer. 400 respondents were taken as a sample from Riyad because of the limited time and resources. For the study, a Judgement sample design was used. Based on the experience or judgment of the researcher, only those respondents are selected who have been using online food ordering apps to order/ dine out food.

For the study, primary as well as secondary data has been used. A structured questionnaire was used to collect Primary data-questionnaire drafted in two parts for this study. Demographic information has been covered in Part I. Part II consists of 22 statements based on several online food ordering factors; a five-point Likert scale is used for this purpose with scale ranging from "1" - (strongly disagree) to "5" - (strongly agree). The sources of secondary data were books, journals, articles, newspapers, and web sites. Collected data were coded and entered the SPSS spreadsheet for the purpose of analyses. After that, EFA and EDAS methods were used for analyzing the data.

\section{DATA ANALYSIS AND INTERPRETATION}

\subsection{Calculations of EFA}

EFA procedure has been used for classifying the factors acting as a motivator for peoples to use online food ordering apps. Factor analysis is a data reduction technique which used to reduce the large number of variables into small number of factors. In this technique correlated variables are combined to independent factors. Before applying factor analysis, the appropriateness of factor analysis has been checked. For this purpose, the Kaiser- MeyerOlkin (KMO) measure of sample adequacy and Bartlett's test of sphericity (BTS) are performed as shown in table 1.

Table $1 \mathrm{KMO}$ and Bartlett's Test

\begin{tabular}{|l|c|c|}
\hline Kaiser-Meyer-Olkin Measure & & .805 \\
of Sampling Adequacy. & & 5258.967 \\
Approx. Chi-Square & Df & 300 \\
Bartlett's Test of Sphericity & Sig. & .000 \\
\hline
\end{tabular}

Source: Primary data

The greater the value of KMO higher will be the reliability of factor analysis. For applying factor analysis, the value of KMO should be greater than 0.5 . From the competitors on the primary data the value of KMO comes out to be 0.805 , which is quite high. It means our sample size was adequate, and factor analysis can be used for reducing the data.

In factor analysis another name of rotated component matrix is Rotated Factor matrix. Factor loading for each variable, i.e., S1, .., S22 are depicted in Table 2. Varimax method of rotation was used here. Factor loading less than 0.6 is neglected and not shown in the table. 
Table 2 Rotated Component Matrix ${ }^{\mathrm{a}}$

Source: Primary data

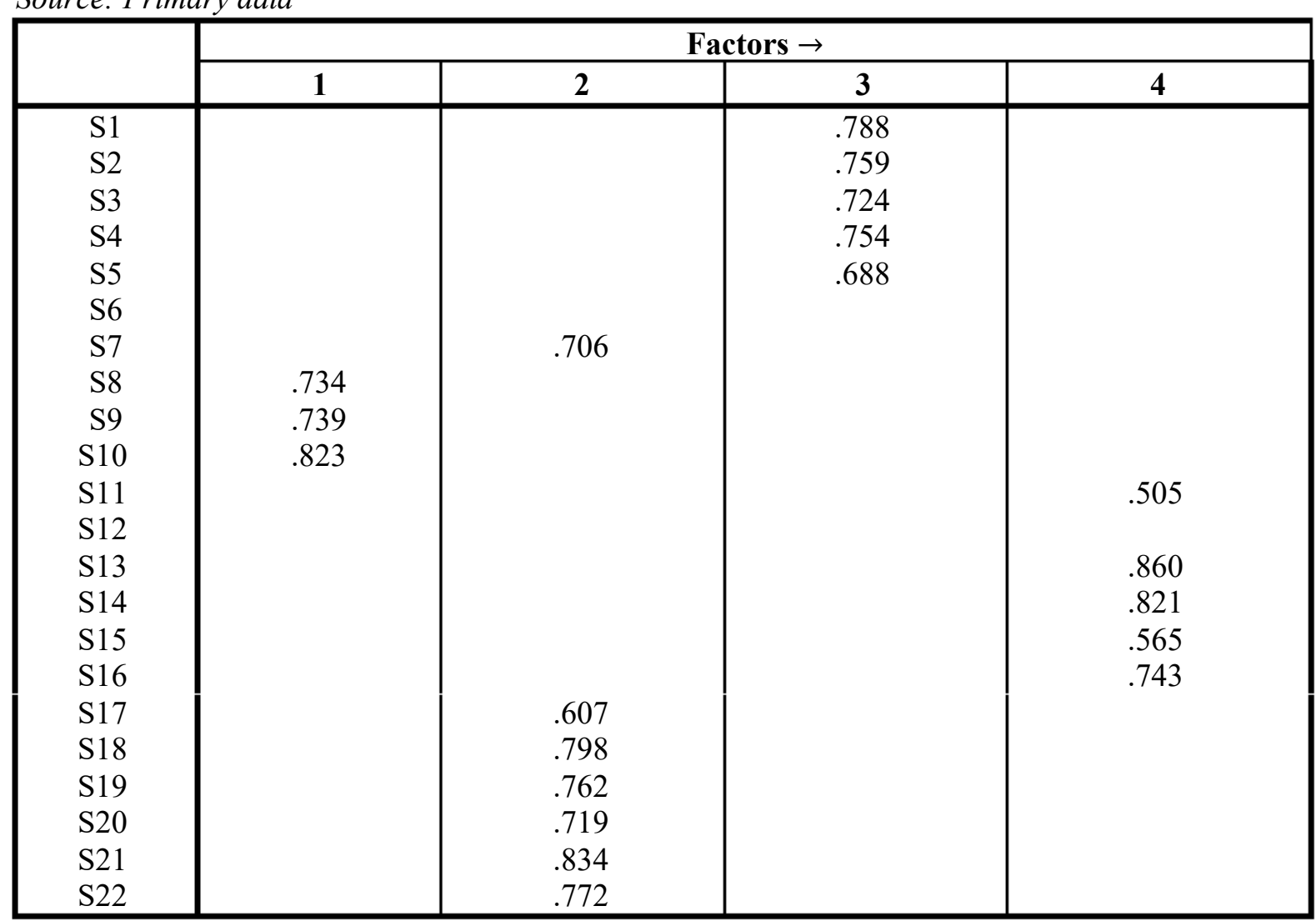

a. Rotation converged in 5 iterations.

This Table depicts that Factor 1 (Right Contents \& Packaging) includes S8-S10 variables. Factor 2 (Offers \& Discounts) includes S7, S17- S22 Variables. Factor 3 (Timely Delivery) includes S1- S5 variables Factor 4 (User-Friendly) includes the variables S11, S13-S16. The Variables $6 \& 12$ were dropped from the study because of having weak loadings (below 0.5).

In table-3b blow we mention the names of various factors along with their loading scores and the average for each factor.

Table 3 Mean values of the factors

\begin{tabular}{|c|c|c|c|c|}
\hline Constructs & Items & Loadings & Average & $\begin{array}{l}\text { Construct } \\
\text { Reliability }\end{array}$ \\
\hline F1 & Right Contents \& Packaging & & 0.770 & 0.917 \\
\hline $\begin{array}{c}\mathrm{RCP} 1 \\
\left(\mathrm{~S}_{8}\right)\end{array}$ & $\begin{array}{l}\text { Packaging of the online food delivery apps attract } \\
\text { me to place the order }\end{array}$ & .734 & & \\
\hline $\begin{array}{c}\mathrm{RCP} 2 \\
\left(\mathrm{~S}_{9}\right)\end{array}$ & $\begin{array}{l}\text { The content of the menu according to my taste } \\
\text { motivates to place the order }\end{array}$ & .739 & & \\
\hline $\begin{array}{l}\mathrm{RCP} 3 \\
\left(\mathrm{~S}_{10}\right)\end{array}$ & $\begin{array}{l}\text { All kinds of food in good packaging motivates me } \\
\text { to order for my family/friends. }\end{array}$ & .823 & & \\
\hline F 2 & Offers \& Discounts & & 0.742 & 0.905 \\
\hline $\begin{array}{l}\text { OFD1 } \\
\left(\mathrm{S}_{7}\right)\end{array}$ & $\begin{array}{l}\text { Offers and discounts offered by the apps motivate } \\
\text { me to place the order }\end{array}$ & .706 & & \\
\hline $\begin{array}{l}\text { OFD2 } \\
\left(\mathrm{S}_{17}\right)\end{array}$ & $\begin{array}{l}\text { Referral coupons motivate me to place an order on } \\
\text { online food delivering apps }\end{array}$ & .607 & & \\
\hline $\begin{array}{l}\text { OFD3 } \\
\left(\mathrm{S}_{18}\right)\end{array}$ & $\begin{array}{l}\text { I prefer online food delivering apps because of the } \\
\text { personalized treatment I may get }\end{array}$ & .798 & & \\
\hline
\end{tabular}


A Unified Factor Analysis and Distance Based Evaluation Approach to Evaluate the Preferences towards Online Food Ordering Applications in Saudi Arabia

\begin{tabular}{|c|c|c|c|c|}
\hline $\begin{array}{l}\text { OFD4 } \\
\left(\mathrm{S}_{19}\right)\end{array}$ & $\begin{array}{l}\text { I place an order even when I don't feel for because } \\
\text { of my expiring loyalty points }\end{array}$ & .762 & & \\
\hline $\begin{array}{l}\text { OFD5 } \\
\left(\mathrm{S}_{20}\right)\end{array}$ & $\begin{array}{l}\text { I feel great when I pay comparatively via online } \\
\text { food delivering apps }\end{array}$ & .719 & & \\
\hline $\begin{array}{l}\text { OFD6 } \\
\left(\mathrm{S}_{21}\right)\end{array}$ & $\begin{array}{l}\text { Various membership benefits offered by online } \\
\text { food delivering apps motivate me }\end{array}$ & .834 & & \\
\hline $\begin{array}{l}\text { OFD7 } \\
\left(\mathrm{S}_{22}\right)\end{array}$ & $\begin{array}{l}\text { Offers given on bulk order many times increases } \\
\text { mine scale of celebrations }\end{array}$ & .772 & & \\
\hline F3 & Timely Delivery & & 0.742 & 0.908 \\
\hline $\begin{aligned} \text { TD1 } \\
\left(\mathrm{S}_{1}\right)\end{aligned}$ & $\begin{array}{l}\text { Fast delivery service motivates me to use online } \\
\text { food delivery apps }\end{array}$ & .788 & & \\
\hline $\begin{array}{r}\mathrm{TD} 2 \\
\left(\mathrm{~S}_{2}\right)\end{array}$ & $\begin{array}{l}\text { Getting food free if not delivered on time } \\
\text { motivates me using online food delivery apps }\end{array}$ & .759 & & \\
\hline $\begin{array}{r}\text { TD3 } \\
\left(\mathrm{S}_{3}\right)\end{array}$ & $\begin{array}{l}\text { I prefer online food delivery apps as I get the food } \\
\text { on time }\end{array}$ & .724 & & \\
\hline $\begin{array}{r}\text { TD4 } \\
\left(\mathrm{S}_{4}\right)\end{array}$ & $\begin{array}{l}\text { I use online food delivery apps as it serves me } \\
\text { fresh and hot food on my location }\end{array}$ & .754 & & \\
\hline $\begin{array}{r}\text { TD5 } \\
\left(\mathrm{S}_{5}\right)\end{array}$ & $\begin{array}{l}\text { Online food delivery apps deliver from restaurants } \\
\text { near you for fast delivery }\end{array}$ & .688 & & \\
\hline F4 & User-friendly & & 0.698 & 0.862 \\
\hline $\begin{array}{l}\mathrm{UF} 1 \\
\left(\mathrm{~S}_{11}\right)\end{array}$ & $\begin{array}{l}\text { Ordering on online food delivery apps is simple } \\
\text { and easy to use }\end{array}$ & .505 & & \\
\hline $\begin{array}{l}\mathrm{UF} 2 \\
\left(\mathrm{~S}_{13}\right)\end{array}$ & $\begin{array}{l}\text { Online food delivery apps have a straightforward } \\
\text { layout }\end{array}$ & .860 & & \\
\hline $\begin{array}{l}\text { UF3 } \\
\left(\mathrm{S}_{14}\right)\end{array}$ & $\begin{array}{l}\text { It is convenient to choose the restaurant from } \\
\text { which my order will be delivered }\end{array}$ & .821 & & \\
\hline $\begin{array}{l}\mathrm{UF} 4 \\
\left(\mathrm{~S}_{15}\right)\end{array}$ & $\begin{array}{l}\text { It is convenient to operate online food delivery } \\
\text { apps for even the kids }\end{array}$ & .565 & & \\
\hline $\begin{array}{l}\text { UF5 } \\
\left(\mathrm{S}_{16}\right)\end{array}$ & $\begin{array}{l}\text { Online food delivery apps remember the previous } \\
\text { order choice, which makes the reorder convenient. }\end{array}$ & .743 & & \\
\hline
\end{tabular}

From the values given in Table 3, it is evident that the average loading of each factor is more than 0.5, which is a good value, and Cronbach's Alpha value of each factor is more than 0.6 , which indicates that the constructs are reliable.

\subsection{Calculations of EDAS}

For the analysis purpose, a prepared questionnaire was filled by 100 users (out of the 400 respondents selected for EFA) of online food ordering applications. Then the decision matrix (table 4) has been prepared by taking the average of the responses. By following the steps of EDAS, discussed in section 4.2, the most preferred online food ordering applications have been ranked, which help in customer decision-making in the selection of the applications. For this method, MS-Excel has been used and the results are presented in table 5,6,7 and 8 .

Table 4 Direct Decision Matrix

\begin{tabular}{|l|c|c|c|c|}
\hline & Beneficial & Non-Beneficial & Beneficial & Beneficial \\
\hline Weightage $\rightarrow$ & 0.35 & 0.15 & 0.25 & 0.25 \\
\cline { 2 - 5 } $\begin{array}{l}\text { Factors } \rightarrow \\
\text { Alternatives } \downarrow\end{array}$ & $\begin{array}{c}\text { Offers \& } \\
\text { Discounts }\end{array}$ & $\begin{array}{c}\text { Right Contents \& } \\
\text { Packaging }\end{array}$ & $\begin{array}{c}\text { Timely } \\
\text { Delivery }\end{array}$ & $\begin{array}{c}\text { User-friendly } \\
\text { App }\end{array}$ \\
\hline HungerStation & 4 & 3 & 5 & 5 \\
\hline Talabat & 4 & 4 & 5 & 5 \\
\hline Daeemdelivery & 3 & 2 & 3 & 2 \\
\hline Walem & 2 & 1 & 2 & 1 \\
\hline \multicolumn{1}{|c|}{$A_{j}$} & 3.25 & 2.5 & 3.75 & 3.25 \\
\hline
\end{tabular}


Table 5 Positive Distance from Average (PDA)

\begin{tabular}{|l|c|c|c|c|}
\hline $\begin{array}{c}\text { Weightage } \rightarrow \\
\text { Factors } \rightarrow \\
\text { Alternatives }\end{array}$ & $\mathbf{0 . 3 5}$ & $\mathbf{0 . 1 5}$ & $\mathbf{0 . 2 5}$ & $\mathbf{0 . 2 5}$ \\
\cline { 2 - 5 } & $\begin{array}{c}\text { Offers \& } \\
\text { Discounts }\end{array}$ & $\begin{array}{c}\text { Right Contents \& } \\
\text { Packaging }\end{array}$ & $\begin{array}{c}\text { Timely } \\
\text { Delivery }\end{array}$ & $\begin{array}{c}\text { User- } \\
\text { friendly } \\
\text { App }\end{array}$ \\
\hline HungerStation & 0.23076923 & 0 & 0.333333 & 0.538462 \\
\hline Talabat & 0.23076923 & 0 & 0.333333 & 0.538462 \\
\hline Daeemdelivery & 0 & 0.2 & 0 & 0 \\
\hline Walem & 0 & 0.6 & 0 & 0 \\
\hline
\end{tabular}

Table 6 Negative Distance from Average (NDA)

\begin{tabular}{|l|c|c|c|c|}
\hline $\begin{array}{c}\text { Weightage } \rightarrow \\
\text { Factors } \rightarrow \\
\text { Alternatives }\end{array}$ & $\mathbf{0 . 3 5}$ & $\mathbf{0 . 1 5}$ & $\mathbf{0 . 2 5}$ & $\mathbf{0 . 2 5}$ \\
\cline { 2 - 5 } & $\begin{array}{c}\text { Offers \& } \\
\text { Discounts }\end{array}$ & $\begin{array}{c}\text { Right Contents \& } \\
\text { Packaging }\end{array}$ & $\begin{array}{c}\text { Timely } \\
\text { Delivery }\end{array}$ & $\begin{array}{c}\text { User-friendly } \\
\text { App }\end{array}$ \\
\hline HungerStation & 0 & 0.2 & 0 & 0 \\
\hline Talabat & 0 & 0.6 & 0 & 0 \\
\hline Daeemdelivery & 0.07692308 & 0 & 0.2 & 0.384615 \\
\hline Walem & 0.38461538 & 0 & 0.466667 & 0.692308 \\
\hline
\end{tabular}

Table 7 Weighted sum of PDA

\begin{tabular}{|l|c|c|c|c|c|}
\hline $\begin{array}{c}\text { Factors } \rightarrow \\
\text { Alternatives } \downarrow\end{array}$ & $\begin{array}{c}\text { Offers \& } \\
\text { Discounts }\end{array}$ & $\begin{array}{c}\text { Right Contents \& } \\
\text { Packaging }\end{array}$ & $\begin{array}{c}\text { Timely } \\
\text { Delivery }\end{array}$ & $\begin{array}{c}\text { User-friendly } \\
\text { App }\end{array}$ & SPi \\
\hline HungerStation & 0.08076923 & 0 & 0.083333 & 0.134615 & 0.298718 \\
\hline Talabat & 0.08076923 & 0 & 0.083333 & 0.134615 & 0.298718 \\
\hline Daeemdelivery & 0 & 0.03 & 0 & 0 & 0.03 \\
\hline Walem & 0 & 0.09 & 0 & 0 & 0.09 \\
\hline & & & & Max SPi & 0.29871795 \\
\hline
\end{tabular}

Table 8 Weighted sum of NDA

\begin{tabular}{|l|c|c|c|c|c|}
\hline $\begin{array}{c}\text { Factors } \rightarrow \\
\text { Alternatives } \downarrow\end{array}$ & $\begin{array}{c}\text { Offers \& } \\
\text { Discounts }\end{array}$ & $\begin{array}{c}\text { Right Contents } \\
\text { \& Packaging }\end{array}$ & $\begin{array}{c}\text { Timely } \\
\text { Delivery }\end{array}$ & $\begin{array}{c}\text { User-friendly } \\
\text { App }\end{array}$ & SNi \\
\hline HungerStation & 0 & 0.03 & 0 & 0 & 0.03 \\
\hline Talabat & 0 & 0.09 & 0 & 0 & 0.09 \\
\hline Daeemdelivery & 0.02692308 & 0 & 0.05 & 0.096154 & 0.173077 \\
\hline Walem & 0.13461538 & 0 & 0.116667 & 0.173077 & 0.424359 \\
\hline & & & & Max SNi & 0.424358974 \\
\hline
\end{tabular}

Table 9 Rank of Alternatives

\begin{tabular}{|l|c|c|c|c|c|c|}
\hline \multicolumn{1}{|c|}{ Alternatives $\downarrow$} & SPi & SNi & NSPi & NSNi & ASi & Rank \\
\hline HungerStation & 0.29871795 & 0.03 & 1 & 0.929305 & 0.96465 & 1 \\
\hline Talabat & 0.29871795 & 0.09 & 1 & 0.787915 & 0.89396 & 2 \\
\hline Daeemdelivery & 0.09 & 0.424358974 & 0.301288 & 0 & 0.15064 & 4 \\
\hline Walem & 0.03 & 0.173076923 & 0.100429 & 0.592145 & 0.34629 & 3 \\
\hline
\end{tabular}

Table 9 shows HungerStation is the most used and preferred application by the people of Saudi Arabia, followed by Talabat, Walem, and Daeemdelivery. "HungerStation was started in 2012 to transform the food industry in the middle east by enabling people to order the food they want when they want it so that they could enjoy their perfect meal from the convenience of their homes or offices. With more than 10000 stores operating in more than 70 cities in Saudi Arabia and Bahrain, HungerStation is the platform to fuel your hunger and satisfy your cravings while enjoying an easy and great ordering experience. No need to look for 
restaurants or grocery numbers anymore! With HungerStation, you can order from your favorite restaurants and stores and pay online or even by cash on delivery!" (https://hungerstation.com/sa-en/about-us)

\section{CONCLUSION}

The customer's perception of online food ordering cannot be generalized; it varies for everyone. Therefore, the perception of a customer is restricted to a particular extent, with the supply of good connectivity and their level of exposure to online food services. The perception of the buyer varies consistently with various similarities and differences that support their individual personal opinions. These personal opinions are affected by some significant factors. The study reveals that the idea of online food ordering appealing more to the younger generation than the older people as they are either not extremely technologyfriendly, or complete technophobes or prefer calling the restaurants as that is what they have been doing for many years now, as this comes close to their level of convenience. It also leads to the maintenance of a personal touch. The study also reveals that timely delivery, discount offers, content \& packaging, and user-friendly apps are the foremost influencing factors for online food ordering. HungerStation and Talabat are the most preferred online food ordering applications by the customers, followed by Walem and Daeemdelivery.

\section{FUTURE IMPLICATIONS}

This research aims to understand consumer perception and buying processes. In future research, the researchers can compare consumer behavior and perceptions of restaurants, traditional food delivery service, and online delivery service. Also, why these online food ordering services are not so popular in rural areas, the factors responsible can be identified, which may help in influencing rural consumers and craft appropriate marketing strategies for the online food delivery market.

Author Contribution: The author read and approved the final manuscript.

Data Availability : No data were used to support this study.

Acknowledgement: The author would like to thank the editors and reviewers for their valuable contributions, which greatly improved the readability of this paper.

Declaration of Conflicting Interests : The author declares no potential conflict of interest with respect to the research authorship and publication for this article.

\section{REFERENCES}

[1] Ghadiyali, N.P.M.S. (2017), A study on customers attitude and perception towards digital app services. Amity Journal of Management, 38.

[2] Goyal, A., \& Singh, N. P. (2007). Consumer perception about fast food in India: an exploratory study. British Food Journal, 109(2), 182-195.

[3] Kimes, S. E. (2011). The current state of online food ordering in the US restaurant industry. Cornell Hospitality Report, 11(17), 6-18.

[4] Anand, R. (2011). A study of determinants impacting consumers food choice with reference to the fast food consumption in India. Society and Business Review, 6(2), 176-187.

[5] Kashyap, M., Kashyap, K., \& Sarda, A. (2013). A study of growth of fast food industry with reference to shift in consumer's buying habits in Nagpur city. International Journal of Application or Innovation in Engineering \& Management (IJAIEM), Special Issue for National Conference on Recent Advances in Technology and Management for Integrated Growth. 
[6] Banerjee, S., Joglekar, A., \& Kundle, S. (2013). Consumer awareness about convenience food among working and non-working women. IJSR-International Journal of Scientific Research, $2(10), 1-4$.

[7] Lee, K., \& Lisa Raiz PhD, M. S. W. (2015). The home-delivered meals program: a promising intervention for suburban older adults living alone. Care Management Journals, 16(4), 195.

[8] Wright, L., Vance, L., Sudduth, C., \& Epps, J. B. (2015). The impact of a home-delivered meal program on nutritional risk, dietary intake, food security, loneliness, and social wellbeing. Journal of nutrition in gerontology and geriatrics, 34(2), 218-227.

[9] Quevedo-Silva, F., Freire, O., Lima-Filho, D. D. O., Brandão, M. M., Isabella, G., \& Moreira, L. B. (2016). Intentions to purchase food through the internet: developing and testing a model. British Food Journal, 118(3), 572-587.

[10] Pigatto, G., Machado, J. G. D. C. F., Negreti, A. D. S., \& Machado, L. M. (2017). Have you chosen your request? Analysis of online food delivery companies in Brazil. British Food Journal, 119(3), 639-657.

[11] Sharma, K., \& Waheed, K. A. (2018). Consumption of online food app services: An exploratory study among college students in Dubai. Middle East Journal of Business, 13(4), 411 .

[12] Kapoor, A. P., \& Vij, M. (2018). Technology at the dinner table: Ordering food online through mobile apps. Journal of Retailing and Consumer Services, 43, 342-351.

[13] Reddy, M. S., \& Pentyala, B. (2019). Customer perception towards on online food ordering. International Journal of Innovative Studies in Sociology and Humanities, 4(2), 102107.

[14] Prasad, S., \& Sharma, M. (2016). Demographic and socioeconomic influences shaping usage of online channel for purchase of food \& grocery. Indian Journal of Marketing, 46(10), 7-21.

[15] Alalwan, A. A. (2020). Mobile food ordering apps: An empirical study of the factors affecting customer e-satisfaction and continued intention to reuse. International Journal of Information Management, 50, 28-44.

[16] Tzeng GH, Chiang CH, Li CW. (2007). Evaluating intertwined effects in e-learning programs: A novel hybrid MCDM model based on factor analysis and DEMATEL. Expert systems with Applications, 32(4), 1028-44.

[17] Saini, C. \& Gupta, N. (2020). Interrelated factors driving the purchase of over-the-top television subscription services: A study using exploratory factor analysis and the decisionmaking trial and evaluation laboratory method. Advanced Marketing Analytics, 6(1).

[18] Kaiser HF. (1958) 'The varimax criterion for analytic rotation in factor analysis', Psychometrika, 23(3), 187-200.

[19] Sudha, A. S. (2019). Application of EDAS Method on Water Requirement in Agriculture. International Journal of Engineering Research \& Technology, 8(12), 558-561. 